\title{
Computerized Laboratory in Science and Technology Teaching: Course in Machine Elements
}

\author{
Ivan KOLAROV \\ Department of Machine Elements, Higher School of Transport \\ "Geo Milev" N 158 str., 1574 Sofia, Bulgaria \\ e-mail: ikolarov@vtu.bg
}

Received: July 2004

\begin{abstract}
The computer registration of physical and mechanical quantities gives a lot of possibilities for machine elements and mechanisms research. The advantages of well-organized computer laboratory both technical and methodological are namely: registration and on-line observation of a number of processes with random speed; replacement of high-cost specialized laboratory equipment; mathematical data processing; solving educational problems by modern technologies.

The purpose of this paper is to present the results of implementation of universal computer system for registering physical and mechanical quantities of elastic coupling, prepared in the laboratory of Machine Elements at the Higher School of Transport, Sofia, Bulgaria. The results are obtained by a special stand and the quantities are registered by a universal interface and software. After mathematical processing a number of characteristics and properties important for practice, such as diagram of friction and dumping in the coupling, shaft angle speed, etc. have been obtained.

The interface and software used allow to students to make the electrical scheme of measuring by them, to acquire basic knowledge for the problem investigated and to acquire self-confidence of solving such problems in practice.
\end{abstract}

Key words: e-learning, true experiment, mathematical treatmen.

\section{Introduction}

The physical and mechanical parameters such as force (moment), linear and angular deformation and speed are typical parameters to be examined in the laboratory of Machine Elements. Their experimental determination gives important information about the serviceability, technical state and properties of machine elements and mechanisms.

The classic examination on machine elements and mechanisms is done on stands specially designed for that purpose and creating conditions of object operation that are close to the real ones. One, two or more parameters are examined at one and the same time. The registration of results is done most often by mechanical, electromechanical, electropneumatic devices, etc. To obtain complete information about the processes studied, electronic devices for registering rapid processes and mathematical data-processing have been produced in industry. The latter are with high prices and are specialized for a limited number of operations. 
Teaching in the laboratory of Machine Elements has to combine classic models of general engineering subjects with fast-developing measuring equipment including the application of computers. The usage of universal computer equipment and software for registering and mathematical processing of electrical quantities obtained from the stands for different topics is quite appropriate under the conditions of a school laboratory.

The purpose of this paper is to present the application of a universal computer system for registering and mathematical analysis of physical and mechanical quantities investigating the characteristic of an elastic coupling in the laboratory of Machine Elements at the Todor Kableshkov Higher School of Transport in Sofia, Bulgaria.

\section{Methods}

A wide range of topics including almost the whole set of machine elements and mechanisms in practice are studied at that laboratory. The base of each examination is measuring characteristic parameters for determining the functional fitness. The parameters searched often changed their values dynamically. They are determined in a theoretical way by models proved in mechanics and experimentally making evaluation of the deviation from the results. The mistake between the results obtained by the two ways is determined. It helps students to understand that the theoretical models existing in mechanics reflect the reality, which has a great impact on their whole engineering education. But to realize these activities it is necessary to have precise measuring equipment allowing true registering of rapid processes.

To carry out laboratory workshops in Machine elements a computer system is tested. It consists of a universal interface with software and a computer. The system is integrated within the school equipment by implementing a diagram shown in Fig. 1.

Sensors and amplifiers are used depending on the physical nature of parameters measured and are electrically matched. A 12-bit interface CMC-S3 and software eProlab for registering and mathematical processing operating in WIN 95/98/XP medium (developed by Dr. Slavko Kocijancic from the University of Ljubljana, Faculty of Education, for mutual work on SI 143008 ComLabSciTech project) are used to test the process of measuring. One of the main basic feature of combination CMC-S3 - eProlab is the flexibility

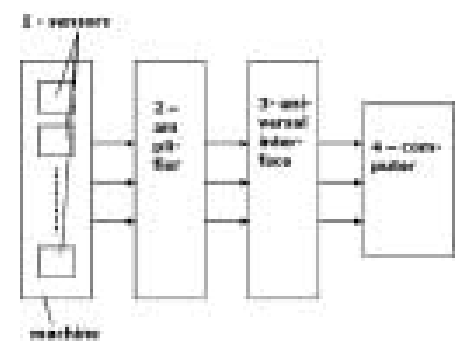

Fig. 1. Diagram of measuring physical and mechanical parameters: 1 - sensor, 2 - amplifier, 3 - universal interface, 4 - computer. 
users to fit their specific sensors choosing the parameters: sensor name, input characteristics (voltages range, number of channels measurement), calibration. By this features procedure "computer measurement" stops to be "closed box" for non-specialists and is more understandable for students. The examinations are done for the needs of workshops on Elastic Coupling.

The main function of the elastic coupling is to reduce (dampen) the dynamic loads between the joined shafts. Representation of a dynamic model is shown in Fig. 2 a, where $\mathrm{T}_{1}, \mathrm{~T}_{2}$ and $\mathrm{Y}_{1}$ and $\mathrm{Y}_{2}$ are torques and momentum of input and output shafts. During the laboratory workshops a coupling with an elastic element made of rubber is examined. Rubber is a material with internal friction with elastic deformation. That is the reason for dampening the dynamic loads between the joined shafts.

The elastic coupling is loaded statically and dynamically on a special stan. The diagram and picture of the stand are shown in Fig. 2 b and 3. The operation of the stand is as follows: The coupling (5) is loaded statically for torsion by a screw-and-nut gear (1) and a spring (2). The coupling is loaded dynamically by an electric engine and crank mechanism (7). The torsion moment in the coupling is measured by the strain-measuring shaft (6), and its angular deformation - by a strain-measuring bar (4). The signals from the strain-measuring shaft (6) and bar (4) are transmitted to a specialized amplifier and a registered by a computer system (Fig. 1).

For dynamic process investigation coefficient of dampening $\psi$ has been introduced. For an elastic coupling it is determined from (Arnaudov, 1980):

$$
\psi=\frac{A_{\text {damp }}}{A_{\text {poten }}}
$$

where $A_{d a m p}$ is the work of the forces of the internal friction in a coupling with deformation (hatched area on the drawing, Fig. 4), $A_{\text {poten }}$ - the mechanical work for coupling deformation (the entire area below the torque). Damping in the coupling is the reason

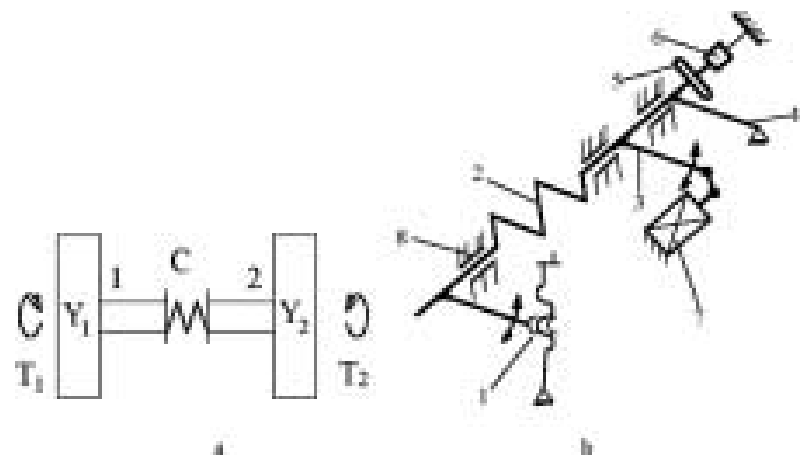

Fig. 2. Representation of a dynamic model (a) and of a diagram of a stand for static and dynamic study (b); 1 - screw-and-nut gear, 2 - cylindrical spring, 3 - flat spring, 4 - strain measuring of the angle of torsion, 5 elastic coupling, 6 - strain measuring shaft for measuring the torsion moment, 7 - electric engine with a crank mechanism, 8 - supports. 


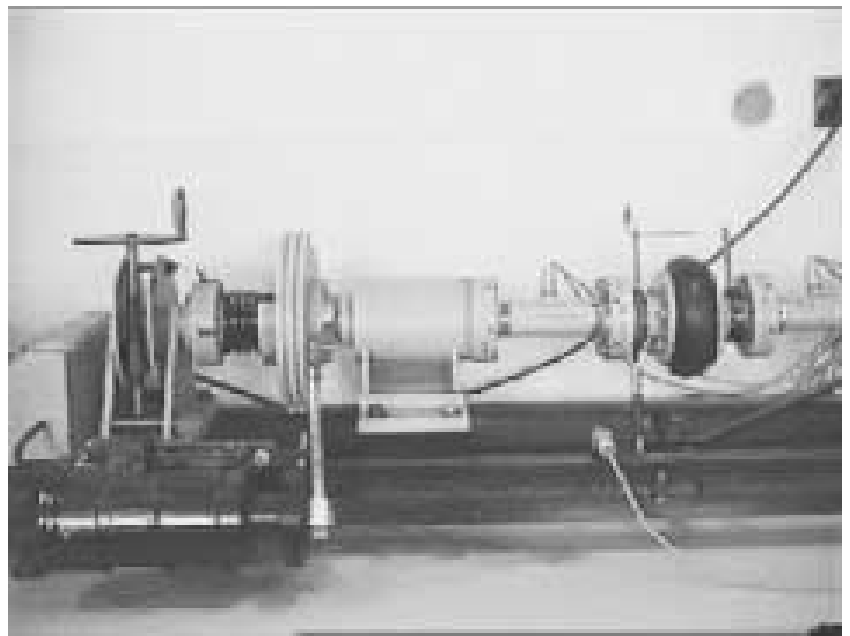

Fig. 3. Picture of the stand "Elastic Coupling".

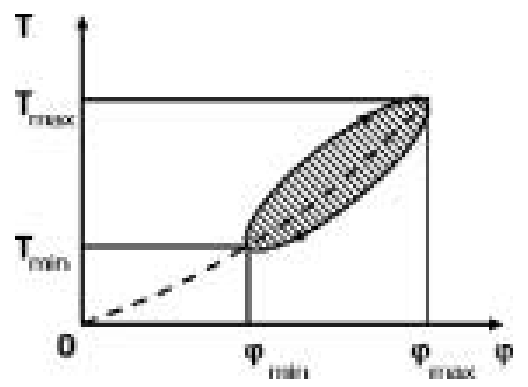

Fig. 4. Drawing presentation of coefficient of dampening $\psi$ for dynamic torque.

when the torque $T_{1}$ dynamically changes the torque $T_{2}$ decrease because of deformation. But because $T_{1}$ defers $T_{2}$ in phase and amplitude a special apparatus for messing is required. That is why these parameters for dynamic loading often are not measured.

\section{Results}

Typical results registered with dynamic loading of an elastic coupling by using computer system introduced above are shown in Fig. $5 \mathrm{a}, \mathrm{b}$ and c. The input $\mathrm{T}_{1}$ and output $\mathrm{T}_{2}$ torques and the angular deformation $\varphi$ have been measured. The dampening ability with dynamic loading has been obtained on the base of registered values. The dynamic study is carried out with a value of the static moment of $0.6 \mathrm{~N} . \mathrm{m}$ and amplitude of the dynamic moment of 8 N.m. The additional diagram images in Fig. $5 \mathrm{a}$ and $\mathrm{b}$ have been obtained after data registering in a digital kind and their introducing into specialized software for mathematical processing. Values of 0.12 and 0.08 have been obtained for coefficient of dampening with static and dynamic study on a coupling. The frequency of changing of $T_{1}$ 


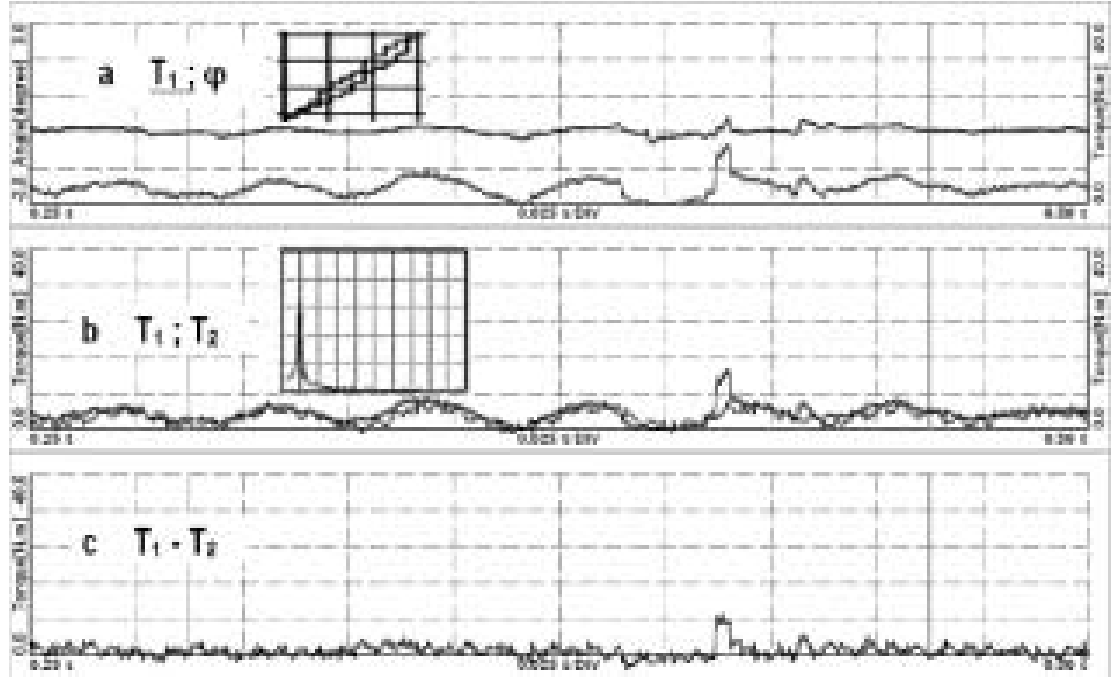

Fig. 5. Results obtained with dynamic loading of a coupling; a - typical results obtained for input $\mathrm{T}_{1}$ torques and angular deformation $\varphi$, (inset drawing 1 presents dampening ability with dynamic loading); $\mathrm{b}-$ input $\mathrm{T}_{1}$ and output $\mathrm{T}_{2}$ torques (inset drawing 2 presents Fourier analyzing of vibration for angular speed determination); $\mathrm{c}-\mathrm{T}_{1}-\mathrm{T}_{2}$ measuring.

has been determined by using the built-in function for Fourier analyzing. In Fig. $5 \mathrm{c}$ the effect of coupling dampening could be seen. A dynamically increasing of $\mathrm{T}_{1}$ estimated on about 9 N.m has been dumped.

Students in laboratory on Machine Elements subject have possibilities to make their own experiments with dynamic loading, to see phenomena and to compare theoretical and experimental results. For this aim a number of mathematical and experiment results have been combined with video clips and presentations.

After a considerable number of workshops in training process could be said students easily master their abilities to work by computer system. They fast acquire knowledge how to deal with software, including built in it mathematical functions.

\section{Conclusion}

The results obtained on the base of testing the computer system sensor - amplifier - universal interface - computer are valuable for teaching the subject Machine Elements. The computer system is used as an oscilloscope with wide possibilities to regulate the time interval of registering the results for online registering physical and mechanical parameters. An elastic coupling has been investigated by using special stand. The amplitude and frequency analysis of input and output torques and angular deformation are obtained rapidly with the help of e-prolab functions built-up in software. This ability of software gives extraordinarily great possibilities solve problems important for machine manufacturing and to substitute high-priced industrial electronic specialized devices. A function for automatic drawing of 2-D dependencies of parameters registered experimentally is built up 
in software. It allows visualizing fast 2-D diagrams after the measuring done without additional mathematical software. More results at the addresses http: / /www . vtu.bg/ 〜ikolarov/workshop/Workshops_P1/workshops_en.htm and http:// www.e-prolab.com/comlab/sttop/sttop-me/index.htm have been presented.

By computerized system students have possibilities to make their own experiments, to see phenomena and compare with theory.

\section{Acknowledgements}

We would like to express my acknowledgements to the Commission of the European Communities, Directorate - General Education and Culture, Leonardo da Vinci Community Vocational Training Program for the financial support and possibility to obtain contemporary results with the experimental study on machine elements and mechanisms while working on SI 143008 project.

\section{References}

Arnaudov, K., et al. (1980). Machine Elements, Tehnika, Sofia (in Bulgarian).

Minchev, N., and V. Grigorov (1980). Vibration Diagnostics of Rotation and Piston Machines, Tehnika, Sofia (in Bulgarian).

I. Kolarov is a lecturer at the Department of Machine Elements, Machine Elements and Design, Higher School of Transport, Sofia, Bulgaria. He teaches the subjects machine elements, machine elements and design, metrology and measurement equipment, computer automated design, engineering and descriptive graphic.

\section{Technikos ir taikomujų mokslų mokymas panaudojant kompiuterizuotas laboratorijas: kursas apie kompiuteriu elementus}

\section{Ivan KOLAROV}

Fizinių ir mechaninių dydžių kompiuterinè registracija suteikia galimybę plèsti kompiuteriu elementų ir mechanizmų tyrimų ribas. Tinkamai organizavus kompiuterinę laboratoriją pasiekiami šie techniniai ir metodologiniai privalumai: daugelio procesų, susijusių su atsitiktiniu greiciu registravimas ir tiesioginis stebejjimas, galimybė atsisakyti brangios specializuotos laboratorinès irangos, matematiniu duomenų apdorojimas; pasitelkiant moderniąsias technologijas palengvinamas edukaciniu problemų sprendimas.

Šiame straipsnyje supažindinama su universalios kompiuterinès sistemos, skirtos elastinio sukabinimo fiziniams ir mechaniniams dydžiams registruoti, taikymo rezultatais. Tyrimas atliktas Sofijos (Bulgarija) Aukštesniojoje transporto mokykloje. Rezultatai gauti naudojant specialu stenda, o dydžiai registruoti naudojant universalią vartotojo sąsaja bei programinę irangą. Atlikus matematinius skaičiavimus buvo gauta daugybe praktiniams darbams svarbių charakteristiku ir savybiu, pavyzdžiui, apskaičiuota trinties diagrama, veleno kampinis greitis ir pan. Patirtis, igyta naudojant vartotojo sąsają bei programinę irangą, leidžia studentams patiems kurti elektronines matavimo schemas, suteikia esminių žinių, reikalingu užduočiu tyrimams atlikti, bei skatina pasitikèjimą savimi, kuris itin reikalingas praktiškai sprendžiant tokias užduotis. 